\title{
The dominance of cyanobacteria in Mediterranean hypereutrophic lagoons: a case study of Cabras Lagoon (Sardinia, Italy)
}

\author{
SILVIA PULINA, BACHISIO MARIO PADEDDA, NICOLA SECHI \\ and ANTONELLA LUGLIÈ \\ Department of Botanical, Ecological and Geological Sciences, University of Sassari, Via Piandanna 4, 07100 Sassari, \\ Italy. E-mail: pulinasi@uniss.it
}

\begin{abstract}
SUMMARY: An intense proliferation of cyanobacteria in Cabras Lagoon was investigated over a period of two years (July 2007 to June 2009). The influence of environmental and meteorological parameters in the lagoon on temporal variations in cyanobacteria orders was assessed. For 17 months, Chroococcales was the only cyanobacterial order observed in the lagoon. Cyanobium-type cells (Reynolds functional group Z) were the most abundant phytoplankton taxon during this period. In the following months, drastic changes in the cyanobacteria assemblages occurred simultaneously with constant, intense rainfall that led to a sudden drop in the lagoon's salinity. The succession of autumn-winter Oscillatoriales (Planktothrix sp. and Pseudanabaena catenata; Reynolds functional group S1) and late spring growth of Nostocales (Aphanizomenon gracile, Aphanizomenon aphanizomenoides, and Anabaenopsis circularis; Reynolds functional group H1) was monitored. Canonical Correspondence Analysis was carried out to quantify the influence of environmental variables, and indicated strong relationships between Chroococcales and salinity, Oscillatoriales and higher values of SRP and the DIN/SRP ratio, and Nostocales and lower nutrient concentrations, the DIN/SRP ratio and salinity.
\end{abstract}

Keywords: cyanobacteria, phytoplankton, coastal lagoons, eutrophication, Sardinia, Mediterranean Sea.

RESUMEN: DOMINANCIA DE LAS CIANOBACTERIAS EN LAGUNAS MEDITERRÁNEAS HIPERTRÓFICAS: El CASO DE LA LAGUNA DE Cabras (CERDEÑa, ITALIA). - Durante dos años (julio 2007-junio 2009) se monitoreó una proliferación intensa de cianobacterias en la laguna de Cabras, así como los parámetros ambientales y climáticos que determinaron sus variaciones temporales. Durante 17 meses, Chroococcales fue el único orden de cianobacterias en la laguna, del cual células similares a Cyanobium (grupo funcional Z según Reynolds) fueron las más importantes en cuanto a abundancia. En los meses siguientes, las cianobacterias sufrieron cambios drásticos, que ocurrieron simultáneamente con lluvia constante e intensa que dio lugar a una caída brusca de la salinidad de la laguna. Se monitoreó también la sucesión de Oscillatoriales en otoño-invierno (Planktothrix sp. and Pseudanabaena catenata; grupo funcional S1 según Reynolds) y el crecimiento en primavera de Nostocales (Aphanizomenon gracile, Aphanizomenon aphanizomenoides, y Anabaenopsis circularis; grupo funcional H1 según Reynolds). Análisis de Correspondencia Canónica permitieron cuantificar la influencia de las variables ambientales, indicando una estrecha relación entre Chroococcales y salinidad, Oscillatoriales y altos niveles de SRP y proporción DIN/ SRP, y Nostocales y bajos niveles de nutrientes, proporción DIN/SRP y salinidad.

Palabras clave: cyanobacteria, fitoplancton, lagunas costeras, eutrofización, Cerdeña, mar Mediterráneo.

\section{INTRODUCTION}

Coastal lagoons are highly dynamic environments that show large spatial and temporal variability in their physical and chemical characteristics in response to the influence of freshwater and marine water inputs.
Moreover, studies have shown that, as a consequence of the high sediment surface area to water volume ratios in Mediterranean coastal lagoons, processes occurring within the sediments and at the water-sediment interface strongly influence the ecosystem metabolism, nutrient budgets, and biota (Castel et al., 1996). 
These processes have been exacerbated by the pressures of human activities on coastal systems, which have dramatically increased in the last few decades and are predicted to continue growing, especially in developed countries (Viaroli et al., 2007). Furthermore, during the summer, the concomitance of the increase in temperature, the lack of wind, and the degradation of organic matter can result in a reduction of oxygen availability, which eventually leads to dystrophic crises (Bachelet et al., 2000).

Nutrient loading may have different impacts on the ecosystem at different times (Glibert et al., 2007). It is well documented that environment degradation due to eutrophication threatens less tolerant phytoplankton species, while favouring the development of cyanobacteria (Scheffer et al., 1997). Recently, a link between hypereutrophic conditions and cyanobacterial blooms has been documented in a number of Mediterranean lagoons (Chomérat et al., 2007).

The intense proliferation of very small cyanobacterial cells $(<2 \mu \mathrm{m})$ and their dominance over other phytoplankton size classes has been studied in a few coastal environments (Del Negro et al., 2007). The results have served to highlight the increasing importance of these small-sized organisms, which for decades have been recognized as the main primary producers in oceans and oligotrophic aquatic ecosystems (Morán, 2007). However, the important role played by small free-living cyanobacteria in Mediterranean coastal blooms and the ecological damage they induce in areas with high trophic levels have yet to be thoroughly investigated (Sorokin et al., 1996).

Here we provide a case study of Cabras Lagoon, a Mediterranean lagoon dominated by cyanobacteria. The lagoon is the most extended shallow-water body in Sardinia (Italy) and one of the most important in the Mediterranean, and its major primary producer is phytoplankton (Sechi et al., 2006). During the last 20 years, eutrophication has become a chronic condition of Cabras Lagoon, often culminating, especially during summers, in localized dystrophic crises that result in an abrupt decrease in production. Already in the early 1980s, Sechi (1982) classified the lagoon as hypereutrophic. In June 1999, a very strong dystrophic event resulted in the death of all aquatic animals, which had a particularly dramatic impact on the local economies, since the fishery is the main source of income for local residents. During this severe dystrophic event there was a bloom of the cyanobacterium Anabaena cf. mucosa Komarkova-Legnerova and Eloranta. Until now, a detailed study of phytoplankton community composition and dynamics in the Cabras Lagoon has not yet been published.

The purpose of this study was therefore to investigate the spatial and temporal dynamics of cyanobacteria in Cabras Lagoon with respect to environmental and metereological conditions during two year-long cycles (from July 2007 to June 2009). In particular, we wanted to assess which ecological conditions determined the drastic changes in the dominance of cyanobacteria orders during the considered period.

\section{MATERIALS AND METHODS}

\section{Description of the study site}

Cabras Lagoon is located on the west coast of Sardinia (Italy), in the Gulf of Oristano (39 $56^{\prime} 37^{\prime} ' \mathrm{~N}$, $08^{\circ} 28^{\prime} 43^{\prime}$ 'E; Fig. 1), and occupies about $23.80 \mathrm{~km}^{2}$, with a mean water depth and maximum of 1.6 and 3 $\mathrm{m}$ respectively. The watershed of the site extends over approximately $430 \mathrm{~km}^{2}$. The input of freshwater into the lagoon is scarce and irregular because of the semiarid Mediterranean climate. Most of the freshwater comes from the small Mare 'e Foghe River, located in the north.

The predominance of agriculture in the region and the release of poorly depurated urban waste account for the high nutrient loads deposited in Cabras Lagoon (Padedda et al., 2010). The resident population of about 38,000 inhabitants is grouped in 19 urban centres, the largest being Cabras, which is located on the southeast coastal side of the lagoon.

During the twentieth century, the lagoon and its watershed underwent several modifications as a consequence of human activities that affected the hydrology and hydraulics of the region. In addition, in the late 1970s, water exchange with the sea was altered by the dredging of a large canal, the Scolmatore (spillway), which connected the lagoon with the adjacent Gulf of Oristano (Fig. 1). The canal was constructed to avoid flooding of adjacent land during the heavy rainfall that occurs in winter. In addition, a cement dam was built into the Scolmatore to prevent further increases in the lagoon's salinity and artificial barriers were constructed to control the fish catch, thereby impeding direct communication between the lagoon and the sea. Now the only link to the sea is via four very narrow creeks that flow into the large canal from the southern part of the lagoon over the barrier (Fig. 1).

The lagoon has a high economic rating due to extensive fishery activities, involving about 300 people, their families, and those involved in related enterprises.

\section{Sampling strategy and analyses}

The reported data concern two yearly cycles (July 2007-June 2009). Fortnightly sampling was carried out in the first year, and monthly sampling in the second year. The samples were collected at three stations: Station 1, near the lagoon's connection with the sea; Station 2, representing intermediate conditions; and Station 3, near the major input of freshwater (Fig. 1).

The cumulative monthly rainfall was provided by the meteorological station at Zeddiani (Rete Agrometereologica Nazionale property), a few kilometres from the northern part of the lagoon. 


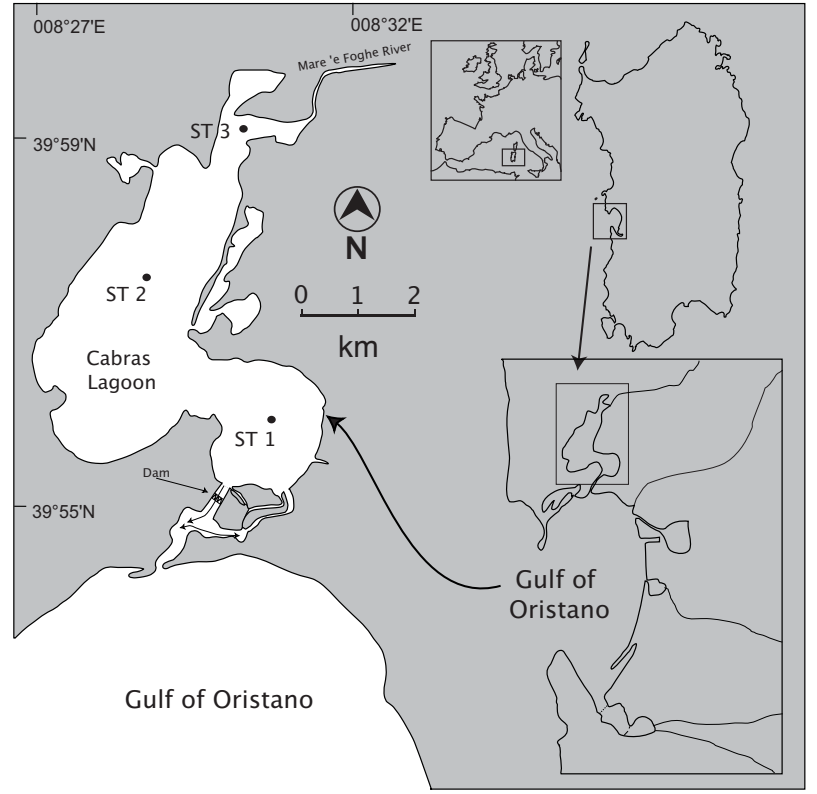

FIG. 1. - Map of Cabras Lagoon, showing its location and the sampling sites.

The in situ water transparency was measured with a Secchi disk, while temperature, salinity, dissolved oxygen, and $\mathrm{pH}$ were determined with a multiparameter probe (YSI 6600V2). Water samples were collected with a bucket from the superficial water layer $(30 \mathrm{~cm}$ depth) and preserved under cold, dark conditions for laboratory analyses of dissolved nutrients (ammonia, $\mathrm{NH}_{3}$; nitrite, $\mathrm{NO}_{2}$; nitrate, $\mathrm{NO}_{3}$; reactive silica, RSi; orthophosphates, SRP; total phosphorus, TP), as described in Strickland and Parsons (1972). The chlorophyll $a$ content was quantified following the method of SCOR-UNESCO (1966). The values of parameters measured in situ were confirmed in laboratory analyses.

Phytoplankton abundance was determined in samples fixed in situ with Lugol's solution, according to Utermöhl's technique (1931). Five-ml subsamples were counted at 200,400, and 1000X magnification in an adequate number of fields. When necessary, the samples were diluted. Phytoplankton biomass was determined following Findenegg's method (1974).

Algal species were identified in non-fixed samples analyzed by light microscope just after they had been collected (using an inverted microscope, Zeiss Axiovert 25) and fluorescence microscopy (using an inverted microscope, Zeiss Axiovert 100, equipped with blue excitation filter blocks, $420-480 \mathrm{~nm}$ ) for the identification of algal species. For species that were difficult to recognize, identification was carried out with scanning electron microscopy (ESEM, Zeiss EVO 10).

Cyanobacteria were identified as described by Komárek and Kováčik (1989), Komárek and Anagnostidis (1998, 2005), Hindák (2000) and Komárek (2005).
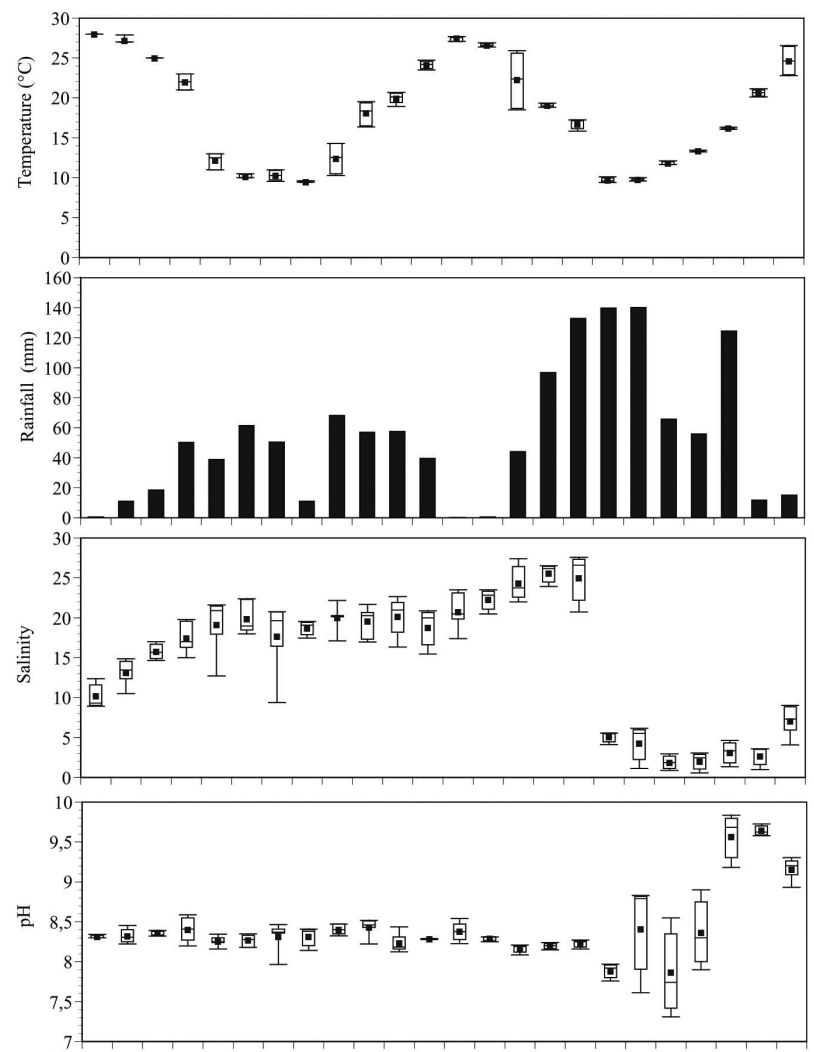

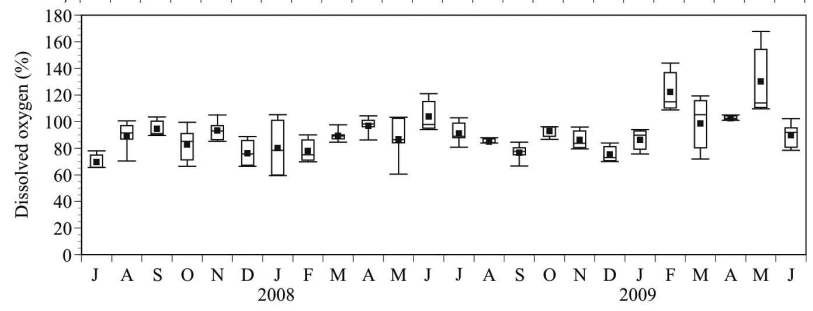

FIG. 2. - Seasonal variations in the main environmental parameters in Cabras Lagoon during the investigation period. The whiskers extend from the 10th percentile to the 90th percentile.

\section{Statistical analyses}

Two-way ANOVA was carried out to test whether the environmental parameters were statistically different among the three stations, with $p<0.05$ considered significant. Differences in the environmental parameters during the two yearly cycles were assessed by testing data obtained in each season using a Student's $t$ test, with $p<0.05$ considered significant.

Canonical correspondence analysis (CCA) (Ter Braak, 1986) was carried out to quantify the influence of environmental variables on cyanobacterial composition with respect to order and species abundances. All canonical axes were used to evaluate the significant variables under analysis by means of a Monte Carlo test (1000 permutations). Data used to construct the environmental and order/species matrixes were squareroot transformed. Statistical analyses were carried out using the software PRIMER (for ANOVA) and MVSP (for CCA). 


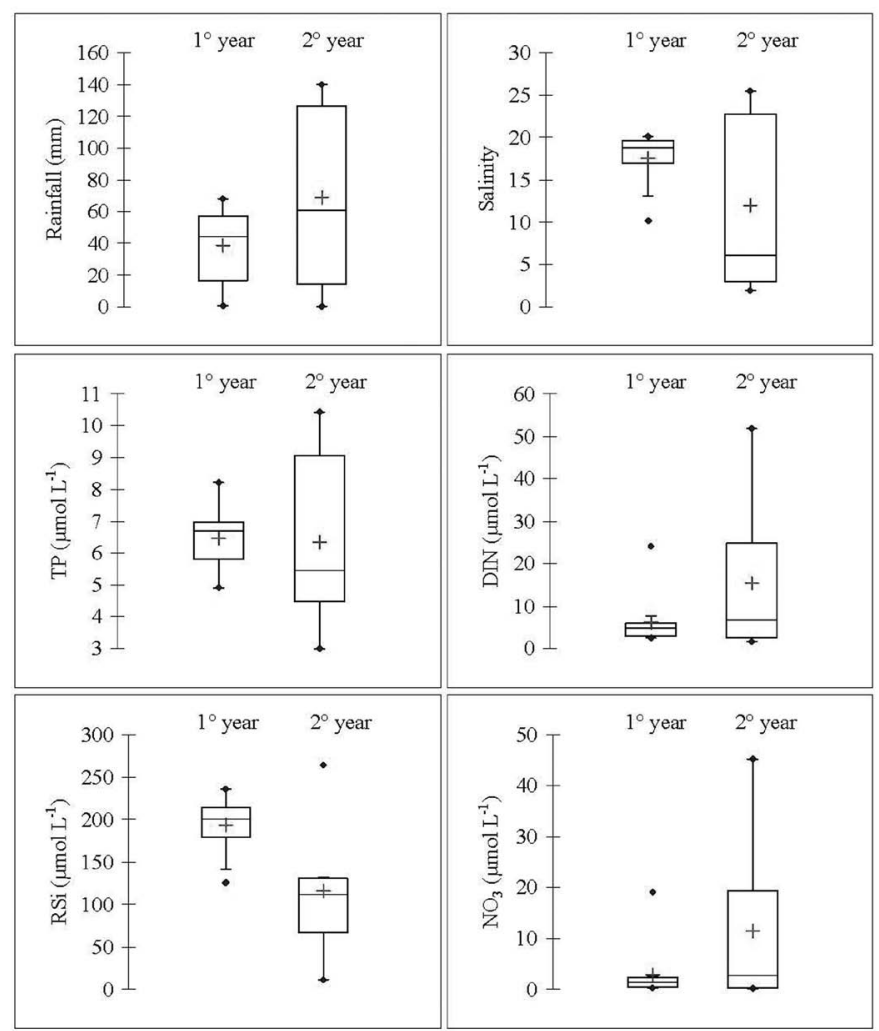

FIG. 3. - Statistical distribution of mean values of the environmental parameters and nutrients that have varied mostly in Cabras Lagoon during the two annual cycles. The whiskers indicate the range containing 1.5 times the interquartile range, and the dots outside the whiskers are outliers .

\section{RESULTS}

\section{Environmental parameters and nutrient dynamics}

Temperatures in the lagoon were, as expected, highest in summer (maximum mean value $28.4^{\circ} \mathrm{C}$, in July 2007) and lowest in winter (minimum mean value $9.4^{\circ} \mathrm{C}$, in February 2008), with the same annual average for the two study cycles $\left(18.2^{\circ} \mathrm{C}\right)$ (Fig. 2). Differences among the sampling stations were not significant (ANOVA, $p>0.05$ ).

Rainfall was greater during the autumn and winter seasons of both years, but was much higher during the second year (Fig. 3). In fact, in the autumn-winter period of 2008-2009 rainfall was intense and prolonged (maximum $140.2 \mathrm{~mm}$, in January 2009) (Fig. 2).

Salinity increased steadily from the beginning of the study (mean value of 10.2) until November 2008 (mean value of 24.9), when it decreased abruptly due to the intense rainfall and the consequent large freshwater input into the lagoon (mean value of 5.0, in December) (Fig. 2). As a consequence, values were lower and oscillated in a wider range in the second year (Fig. 3 ). A clear and consistent spatial salinity gradient was observed, with the values decreasing from Station 1 to Station 3, consistent with the proximity to seawater exchange and the freshwater input respectively.

Rainfall and salinity were the only two variables that differed significantly between the two cycles and
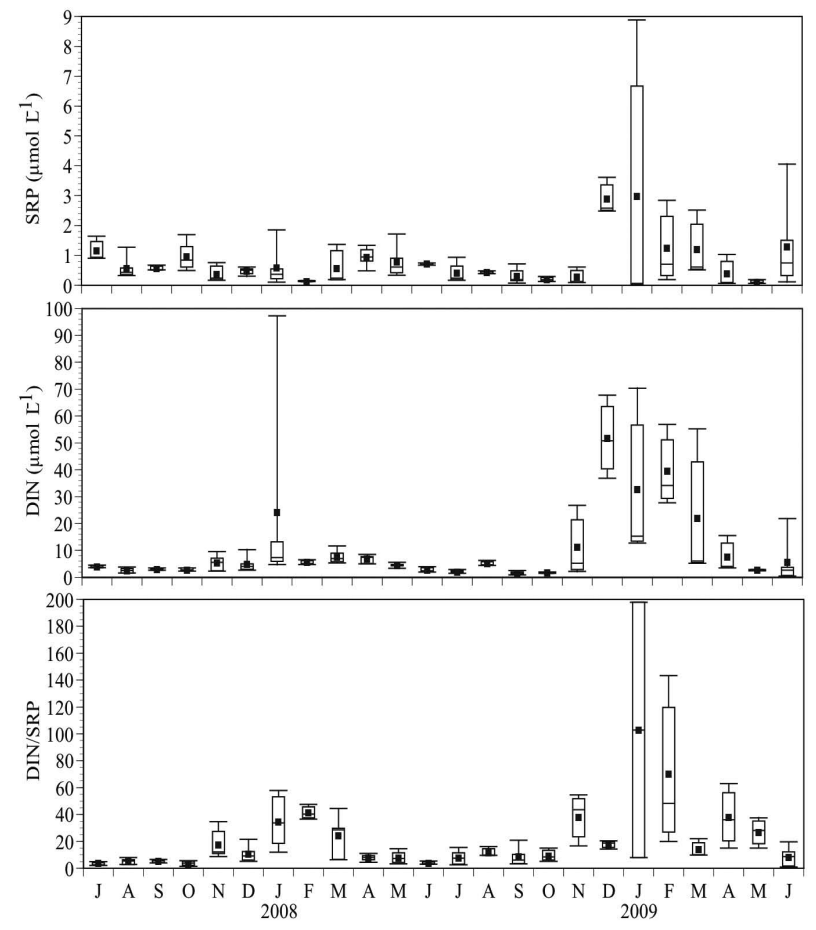

FIG. 4. - Seasonal variations in the main nutrients and the DIN/SRP ratio in Cabras Lagoon during the investigation period. The whiskers extend from the 10th percentile to the 90th percentile. 
did so at the seasonal level: in autumn for rainfall (Student's $t$ test, $p<0.05$ ) and in winter, spring, and summer for salinity (Student's $t$ test, $p<0.05$ ).

Regarding nutrient availability for phytoplankton growth, SRP and Dissolved Inorganic Nitrogen (DIN $\left.=\mathrm{N}-\mathrm{NH}_{3}+\mathrm{N}-\mathrm{NO}_{2}+\mathrm{N}-\mathrm{NO}_{3}\right)$ concentrations were consistently high (Fig. 4), with annual mean values greater in the second year than in the first (Fig. 3). The maximum peaks occurred during the autumn-winter period of 2008-2009, when the mean DIN and SRP in the lagoon was $>50 \mu \mathrm{Mol} \mathrm{N} \mathrm{L}{ }^{-1}$ and almost $3 \mu \mathrm{Mol} \mathrm{P}$ $\mathrm{L}^{-1}$ respectively. ANOVA revealed significant seasonal differences between the three stations: in winter, for both DIN and SRP $(p<0.05)$ and in summer only for SRP $(p<0.05)$. During these seasons, the highest values of the two parameters were recorded at Station 3.

The mean values of the DIN/SRP ratio were low $(<12)$ during most of the sampling months (Fig. 4). The highest mean value recorded (maximum mean value 103) concurred with the highest peaks of DIN in the winter of the second year-long cycle.

\section{Phytoplankton dynamics}

During the investigation period, the most important phytoplankton class in the lagoon was Cyanophyceae, which was regularly detected and reached very high densities during the two years of the study (over $10^{9}$ cells $1^{-1}$ ). This class dominated all other classes, usually accounting for $>80 \%$ and only rarely $<50 \%$ of total phytoplankton density throughout most of the study. By contrast, due to the reduced size of these cyanobacterial cells, the biomass contribution of this class was relatively small, amounting only in a very few cases to $>50 \%$ of the total phytoplankton biomass (Fig. 5).

TABLE 1. - Mean, maximum, and minimum of density and biomass of the cyanobacteria observed in Cabras Lagoon during the two annual cycles of this study.

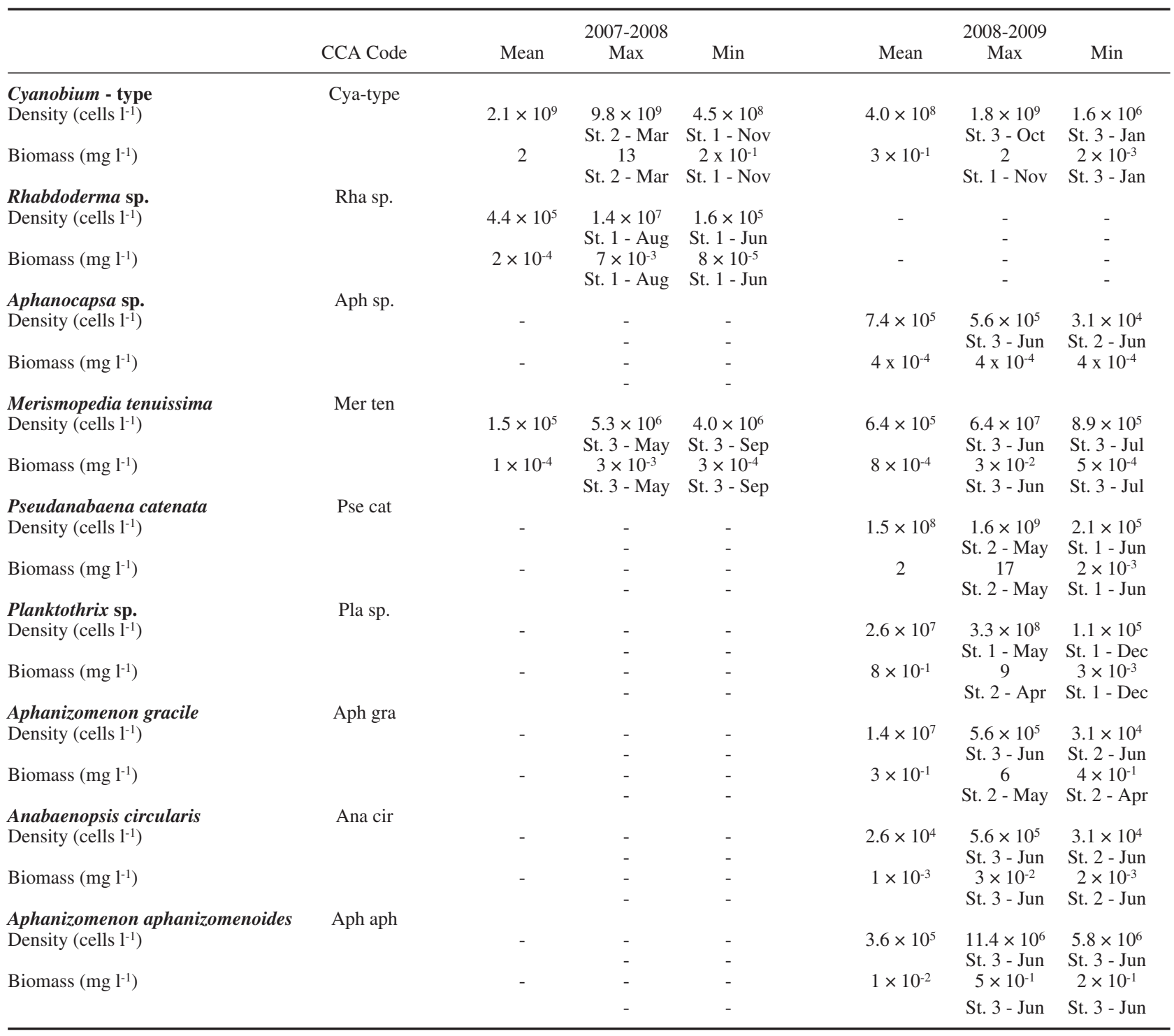




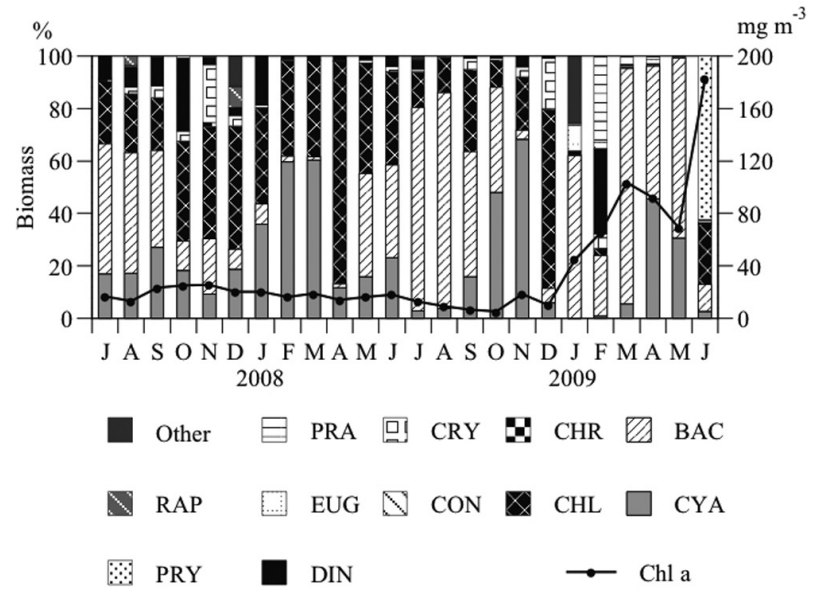

FIG. 5. - Seasonal dynamics of the biomass of the phytoplankton classes in Cabras Lagoon during the investigation period. Data are the mean values obtained from the three sampling stations. PRA, Prasinophyceae; CRY, Cryptophyceae; CHR, Chrysophyceae; BAC, Bacillariophyceae; RAP, Raphydophyceae; EUG, Euglenophyceae; CON = Conjugatophyceae; CHL, Chlorophyceae; CYA, Cyanophyceae; PRY, Prymnesiophyceae; DIN, Dinophyceae;

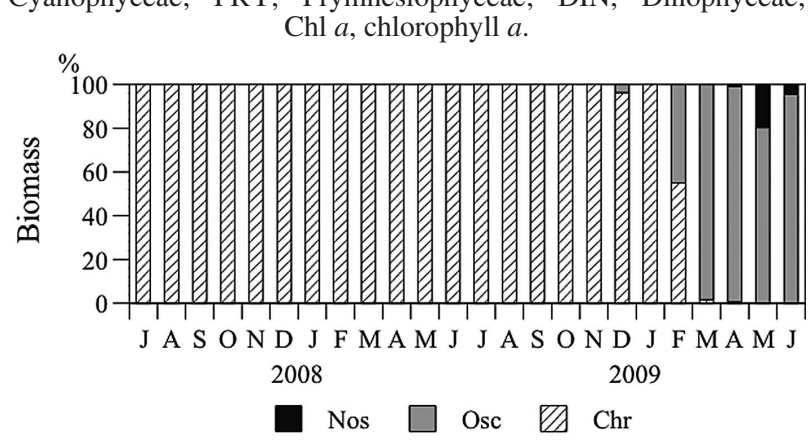

FIG. 6. - Seasonal dynamics of the biomass of Chroococcales (Chr), Oscillatoriales (Osc), and Nostocales (Nos) in Cabras Lagoon during the investigation period. Data are the mean values obtained from the three sampling stations.

The dynamics of chlorophyll $a$ during the first yearlong cycle were relatively constant, with mean values $<20 \mathrm{mg} \mathrm{m}^{-3}$, whereas during the second cycle there was a large increase corresponding to the simultaneous appearance of large-cell species belonging to Bacillariophyceae and Prymnesiophyceae (Fig. 5).

Nine species of cyanobacteria were identified, belonging to the following orders (Table 1): Chroococcales (4), Oscillatoriales (2) and Nostocales (3). For the first 17 months, cyanobacteria were exclusively represented by Chroococcales (Fig. 6), including a species probably belonging to the genus Cyanobium Rippka and Cohen-Bazire, which includes both phycocyanin and phycoerythrin-rich strains (Crosbie et al., 2003). This species was always present and at all three stations was the most abundant phytoplankton taxon (Fig. 7). During the same period, other Chroococcales, i.e. Merismopedia tenuissima Lemmerman and Rhabdoderma sp., were observed, but their presence was very sporadic and their abundance not significant (Fig. 7). Aphanocapsa sp. was detected only during the last month of sampling (Fig. 7).
The phytoplankton composition in the lagoon remained the same until the end of 2008, when a strong increase in the amount of rainfall and the consequent drop in salinity coincided with a change in distribution. Specifically, while the presence of Cyanobium-like species became less important, species of the order Oscillatoriales appeared, beginning with Planktothrix sp. (December 2008) and followed by Pseudanabaena catenata Lauterborn (February 2009) (Fig. 7). The contribution of these species increased during the last period, reaching an abundance and biomass equivalent to $>90 \%$ of all cyanobacteria at all three stations (Fig. 6).

During the spring of 2009, species belonging to the order Nostocales also appeared, initially only Aphanizomenon gracile (Lemm.) Lemm., in April and May, followed by Aphanizomenon aphanizomenoides (Forti) Horecká et Komárek and Anabaenopsis circularis (G.S. Weast) Woloszyńska et Miller in June (Fig. 7).

Among the other classes of phytoplankton, small Chlorophyceae, Chlorella sp., and Monoraphydium minutum (Näg.) Kom.-Legn. were the most abundant at all three stations during the first year-long cycle (maximum abundance reached in autumn and spring). Beginning in January 2009, simultaneously with a de-

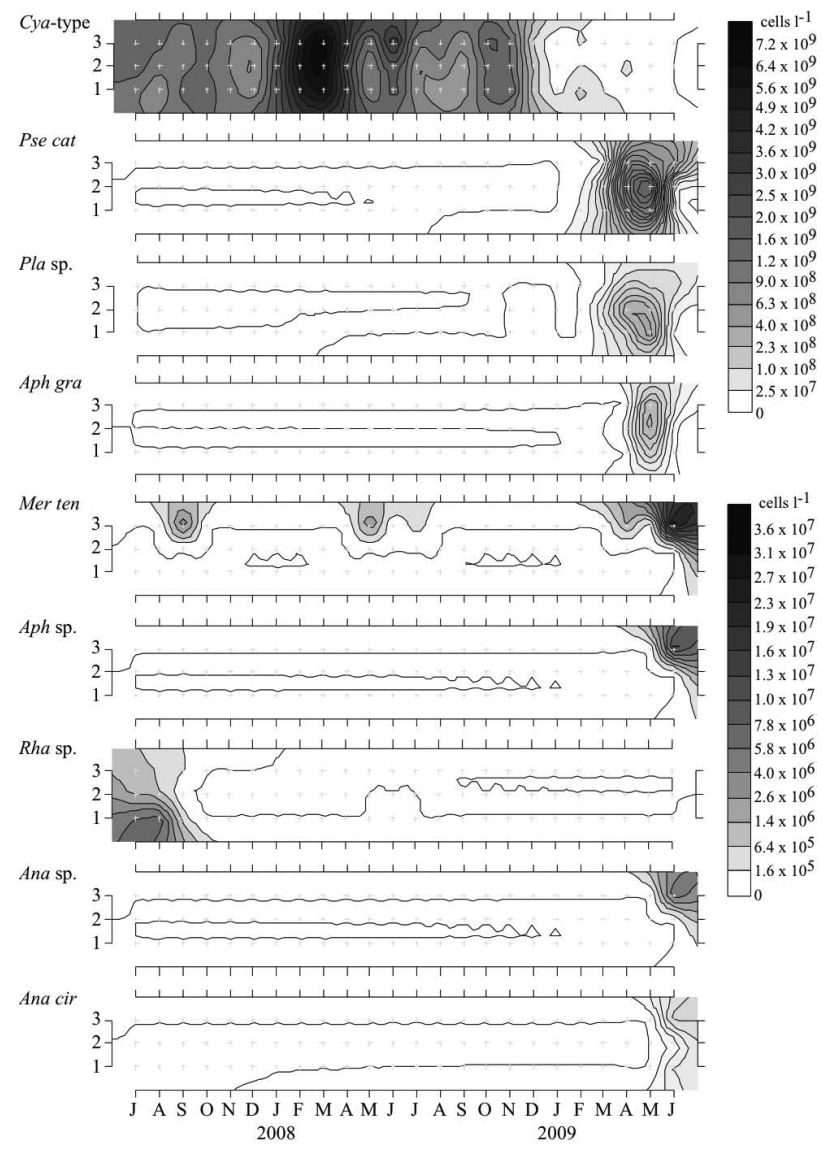

FIG. 7. - Seasonal variations in the abundance of cyanobacterial species at the three sampling stations of Cabras Lagoon $(1,2,3)$ during the investigation period. For abbreviations, see Table 1. 


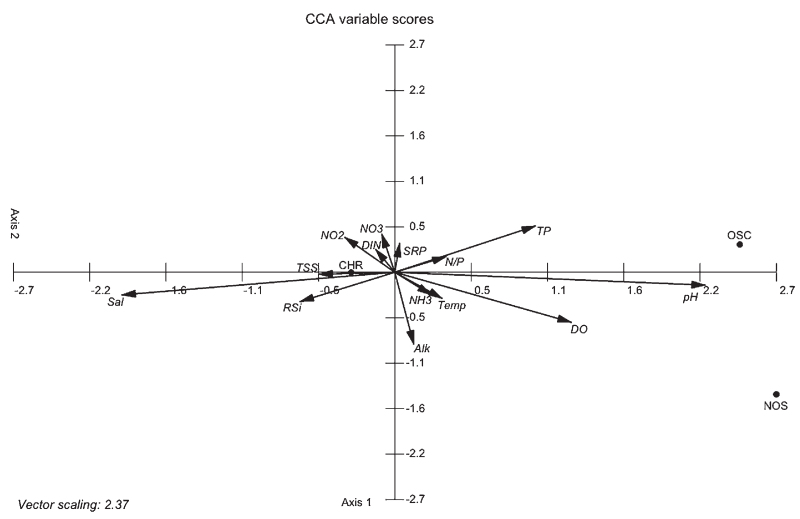

FIG. 8. - Canonical correspondence analysis (CCA) of the relationship orders-environment. (DO, Dissolved Oxigen; Temp, Temperature; Sal, Salinity; Alk, Alkalinity; TSS, Total Solids in Suspension; NO3, Nitrate; NO2, Nitrite; NH3, Ammonia; DIN, Dissolved Inorganic Nitrogen; RSi, Reactive Silica; TP, Total Phosphorus; SRP, orthophosphates; N/P, DIN/SRP. For abbreviations of orders, see Fig. 6).

crease in Chroococcales, the eukaryotic phytoplankton composition became more varied. In winter, small cells of Dinophyceae Heterocapsa rotundata (Lohmann) Hansen 1995 (formerly Katodinium rotundatum (Lohmann) Loeblich III 1965) and of Prasinophyceae Pyramimonas sp. were detected in large amounts. During the spring, the Bacillariophyceae Cyclotella sp. and Chaetoceros sp. were particularly abundant, while in summer there was a bloom of the Prymnesiophyceae Prymnesium sp.

\section{Correlation with environmental parameters}

In a CCA of orders of cyanobacteria, the first two axes of the CCA accounted for $84.8 \%$ of the total variance $(79.6 \%$ for the first axis and $5.6 \%$ for the second) in cyanobacterial orders and environmental data. The orders-environment correlation between 14 environmental variables and the three orders was 0.96 for the first axis and 0.88 for the second. Monte Carlo tests showed that all canonical axes were significant $(p<0.001)$.

CCA was also carried out for cyanobacterial species, with the first two axes accounting for $88.36 \%$ ( $80.74 \%$ for the first axis and $7.62 \%$ for the second) of the total variance of species and environmental data. The species-environment correlation between the 14 environmental variables and the nine species was 0.97 for the first axis and 0.58 for the second. Monte Carlo testing again showed that all canonical axes were significant $(p<0.001)$.

CCA showed the strong relationship between the order Chroococcales (almost exclusively represented by Cyanobium-type species) and salinity (Fig. 8). $M$. tenuissima was observed constantly during the summer months; its presence was related to high temperatures, whereas the outlying position of Aphanocapsa sp. was consistent with its appearance only during a very short period (Fig. 9). A. aphanizomenoides, A. gracile, and

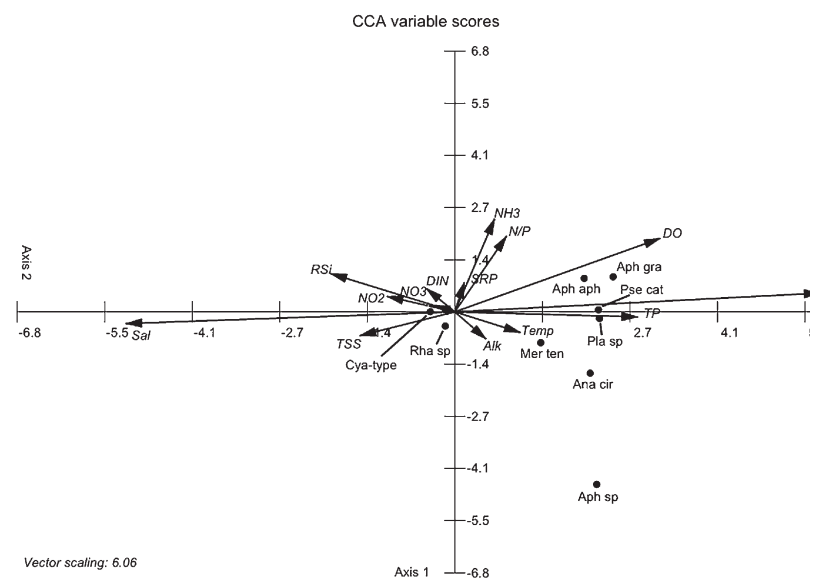

FIG. 9. - Canonical correspondence analysis (CCA) of the relationship species-environment. (DO, Dissolved Oxygen; Temp, Temperature; Sal, Salinity; Alk, Alkalinity; TSS, Total Solids in Suspension; NO3, Nitrate; NO2, Nitrite; NH3, Ammonia; DIN, Dissolved Inorganic Nitrogen; RSi, Reactive Silica; TP, Total Phosphorus; SRP, orthophosphates; N/P, DIN/SRP. For species abbreviations, see Table 1).

A. circularis were positively correlated with physical parameters, i.e. $\mathrm{pH}$ and DO (A. aphanizomenoides, $A$. gracile) and temperature and alkalinity (A. circularis) (Fig. 9). This tendency was also clearly reflected at the order level, whereas the presence of Oscillatoriales was mainly related to nutrients (TP and DIN/SRP) and $\mathrm{pH}$ (Fig. 8). The presence of both Oscillatoriales and Nostocales was negatively correlated with salinity.

\section{DISCUSSION}

During the 2-year investigation period, the hypereutrophic character of Cabras Lagoon was confirmed and the main representatives of its phytoplankton were identified; specifically, cyanobacteria predominated at all three stations and in almost all of the samplings.

The intense proliferation of cyanobacteria in coastal eutrophic ecosystems at all latitudes is well documented in several studies (Kanoschina et al., 2003; Sorokin et al., 1996; Gasiūnaite et al., 2005). In the Mediterranean basin, in lagoons similar to Cabras Lagoon, different orders of cyanobacteria have been observed, depending on the environmental conditions and the season. In the hypereutrophic Bolmon Lagoon in the south of France, a permanent dominance of cyanobacteria was observed. The seasonal pattern was characterized mainly by Planktothrix agardhii (Gomont) Anagnostidis et Komárek in winter, colonial Chroococcales in spring, Pseudanabaenaceae in summer, and $P$. agardhii in autumn and then in winter again (Chomérat et al., 2007). A similar situation, with a persistent dominance of Oscillatoriales, was described for the hypereutrophic Albufera Lagoon in Spain (Romo and Miracle, 1993). The occurrence of small single cyanobacteria has been reported in other Mediterranean lagoons (Del Negro et al., 2007). In the hypereutrophic lagoon system of Comacchio (NW Adriatic Sea, Italy), an extremely in- 
tense bloom of Chroococcales that persisted for many years, resulted in the collapse of that ecosystem (Sorokin et al., 1996).

While picocyanobacteria have long been recognized as important and typical biological components of oceans and, in general, of oligotrophic ecosystems (Morán, 2007), during the last few years they have been increasingly reported in brackish and eutrophic environments (Paoli et al., 2007). The reasons for this expansion are largely unknown but may involve physical variables or alterations in nutrients and/or grazers (Sorokin et al., 1996). It is also true that Carrick and Schelske (1997) argued thoroughly that the importance of small phytoplankton in productive waters may have been overlooked because of some methodological problems or because this component was not considered during routine assessments in this kind of environment.

In Cabras Lagoon, Chroococcales, especially with small single Cyanobium-type cells, was the only cyanobacterial order present for a period corresponding to the first 17 months, i.e. for about $3 / 4$ of the entire study. Despite the characteristic change of seasons, in this period the environmental conditions (especially salinity and nutrients) were relatively more stable than in the following semester. This situation could have favoured the persistence of an intense dominance of the Cyanobium-type species throughout this long initial period. According to the idea of considering ecological categories of phytoplankton in terms of functional groups, Reynolds et al. (2002) assigned unicellular prokaryotic picoplankton to the functional group $\mathrm{Z}$ (photic layers of oligotrophic lakes); however, Huszar et al. (2000) suggested a more eutrophic assignation (functional group X1; shallow mixed layers in enriched conditions) for high biomass forming species of certain coastal lagoons. Recently, Padisàk et al. (2009) suggested classifying them in functional group $\mathrm{K}$ (shallow, nutrient rich water columns). It is evident that further consideration and clarification at a more general level of the template of functional groups are necessary for a less uncertain attribution of our Cyanobium-type species.

In most published scientific works, free-living small-sized cyanobacteria are described under the generic name "Synechoccocus sp." (Komárek and Anagnostidis, 1998). The genus Cyanobium has been reported in coastal lagoons in a few cases, although many of the organisms described in these studies as Synechoccocus-type corresponded instead to the genus Cyanobium (Komárek and Anagnostidis, 1998). For example, in 1989, Andreoli et al. provided a detailed report of picocyanobacterial cells in Santa Gilla Lagoon (Sardinia, Italy); but, according to current information, the cells may well have been Cyanobium (Komárek and Anagnostidis, 1998). Among the described species of the genus Cyanobium, those most similar to the cells observed in Cabras Lagoon, based on morphological and ecological characteristics, are Cyanobium bacil- lare (Butcher) J. Komárek, J. Kopeckà and V. Cepàk and Cyanobium plancticum (G. Drews, H. Prauser and D. Uhlmann) J. Komárek, J. Kopeckà and V. Cepàk. However, there are few cytomorphological and/or molecular biological data to date (Crosbie et al., 2003), and the infrageneric taxonomy of this genus is still incomplete (Komárek and Komárková-Legnerová, 2002).

The results obtained from the Cabras Lagoon during the two year-long cycles provided evidence of a strong relationship between the occurrence of Cyanobiumlike species and the salinity of the water. The presence of these cells in the lagoon decreased enormously only after the strong rainfall in the autumn and winter of 2008-2009, when the large input of freshwater into the lagoon caused a decrease in salinity. A strict correlation between Cyanobium sp. and salinity was also observed in the Ebro estuary (Spain), where an increase in this species was directly proportional to the increase in salinity (Pérez and Carrillo, 2005).

In Cabras Lagoon, the sudden decrease in both salinity and Cyanobium-type species abundance was accompanied by the appearance of typical freshwater species, i.e. Planktothrix sp. and P. catenata. These filamentous cyanobacteria belong to the functional group $\mathrm{S} 1$, that includes only shade-adapted species that live in turbid mixed layers (Reynolds et al., 2002; Padisàk et al., 2009). That the occurrence of these cyanobacteria is favoured by conditions of high nutrient availability, in particular phosphorus, and low-light conditions has been well documented (Scheffer et al., 1997) and agrees with our results. Specifically, we observed that strong rainfall resulted in a large-scale input of nutrients and materials from rivers, as demonstrated by a maximum SRP, an increase in the turbidity of the water, and maximum values of total solids in suspension (data not reported).

The Oscillatoriales first appeared in the lagoon in winter but reached their maximum abundance and biomass in spring, as was also the case in the above-described Bolmon Lagoon (France) and Albufera Lagoon (Spain). In the former, during the study cycle, Oscillatoriales were dominant throughout, reaching a maximum in spring and a minimum in summer. During the entire year, the salinity of this lagoon was similar to that of Cabras Lagoon during the period when Oscillatoriales were present. Indeed, the intense proliferation of this cyanobacteria order in Cabras Lagoon in winter supported the hypothesis proposed in studies of the Bolmon and Albufera Lagoons. At these sites, the mild winters and hot summers, typical of the Mediterranean climate, modified the characteristic patterns observed at higher latitudes, where filamentous cyanobacteria generally dominate the phytoplankton in late summer but decline during the cold period (Chomérat et al., 2007).

We hypothesize that the intense proliferation of phytoplankton, in particular of Planktothrix sp. and $P$. catenata, which were the dominant species in spring, led to the depletion of nutrients later in the season, 

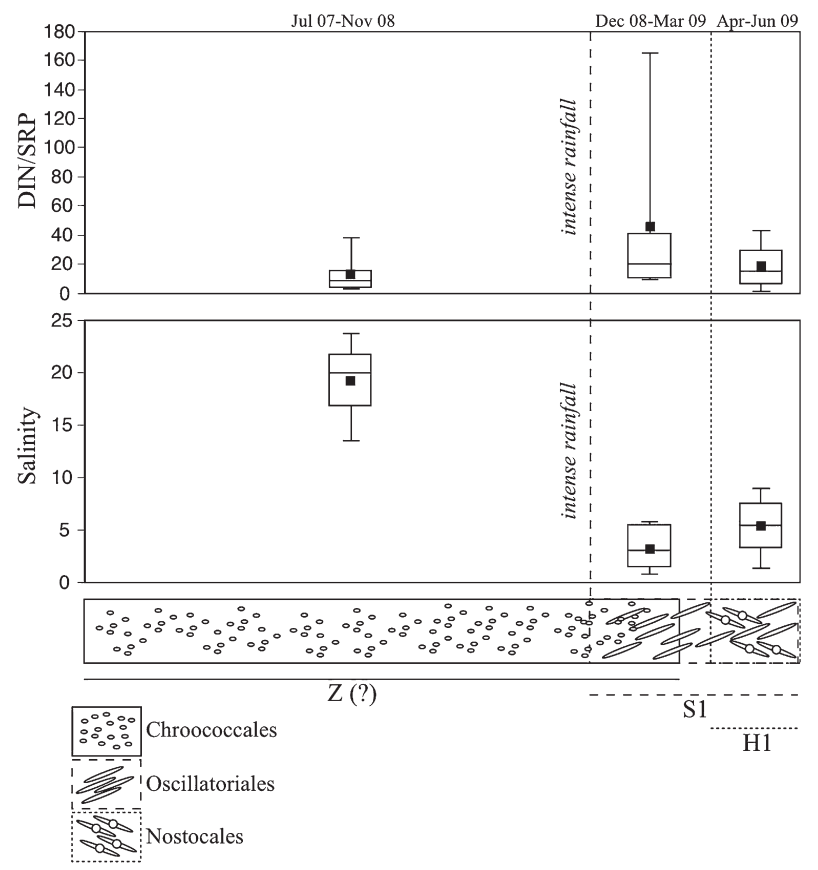

FIG. 10. - Conceptual model of the cyanobacteria succession that affected Cabras Lagoon during the investigation period. The whiskers extend from the 10th percentile to the 90th percentile.

which favoured heterocystous nitrogen-fixing species, initially A. gracile and then A. aphanizomenoides and A. circularis. Reynolds et al. (2002) classified these species into functional group H1 (eutrophic, both stratified and shallow lakes with low nitrogen content). In fact, the CCA results show a strong positive relationship between Oscillatoriales and nutrients and a negative correlation between Nostocales and the different forms of inorganic nitrogen. It also confirmed that the increased abundance of Nostocales species occurred concurrently with maxima of $\mathrm{pH}$ and $\mathrm{DO}$, probably due to their own intensive proliferation. Moreover, the presence of A. circularis, a species with high demands for light and warmth (Komárek, 2005), was favoured by the high temperatures, which accounts for its presence in the lagoon only in June.

In the succession dynamic of the three orders (Chroococcales $\rightarrow$ Oscillatoriales $\rightarrow$ Nostocales) and their correspondent functional groups $(\mathrm{Z} \rightarrow \mathrm{S} 1 \rightarrow \mathrm{H} 1)$, temporal variations in the DIN/SRP ratio were also clearly important, as indicated by the CCA results. Thus, the dominance of Cyanobium-type species during the first year and a half of the study, coincided with a low DIN/SRP ratio. After intense rainfall, there was a strong increase in the DIN/SRP ratio induced by nutrient input from the watershed, which, in turn, could have favoured the dominance of Oscillatoriales. After the DIN/SRP ratio had reached its maximum peaks, there was a shift towards a reduction of values but in coincidence with low salinity of the water. This new condition was less than optimal for Cyanobium-like species and could have favoured the growth of nitrogen-fixing species, specifically those belonging to the order Nostocales. This point highlights the necessity of detailed studies on the nitrogen fixing capacity of $C y$ anobium species as it is only currently supposed based on the well documented capacity of the Chroococcales species, which have a strict genetic link to the Cyanobium genus (e.g. Synechoccocus, Stal and Zehr, 2008).

Considering Scheffer et al. (2001), the observed phytoplankton succession can also be interpreted in terms of different "dynamic regimes" of Cabras Lagoon during the 2-year study period (Fig. 10). In the longer first period of 17 months (high salinity, low DIN/SRP), Cabras Lagoon was characterized by cyanobacteria of functional group Z. This state abruptly changed towards a second regime. This shift was caused by an external perturbation (exceptional rainfall) which was so intense that it drove the system into the basin and led to a new state (high nutrient availability, high DIN/SRP, low salinity), characterized by cyanobacteria of functional group S1. Cabras Lagoon expressed its reduced resilience (in the sense of Scheffer et al., 2001) by suddenly undergoing another shift (low DIN/ SRP, low salinity) caused by an internal factor (nutrient depletion due to phytoplankton growth). The latter state was characterized by the increased abundance of cyanobacteria of functional group H1. However, we believe that these observations should be elaborated by considering a longer time series of data. This would enable us to evaluate the relationships which link the intensity and nature of perturbations with the resilience of the lagoon.

Concluding, this study represents an implementation of the knowledge on the cyanobacteria dynamics in hypereutrophic Mediterranean lagoons. Our findings provide evidence of the strong relationships between Chroococcales (Cyanobium-like species) and salinity, Oscillatoriales (Planktothrix sp. and Pseudanabaena catenata) and higher values of SRP and the DIN/SRP ratio, and Nostocales (Aphanizomenon aphanizomenoides and Anabaenopsis circularis) and lower nutrient concentrations, the DIN/SRP ratio and salinity.

\section{ACKNOWLEDGEMENTS}

This study is an elaboration of the results of the researches supported by Com.Bio.Ma. (Centro di Competenza Biodiversità Marina). The authors thank Salvatore Marceddu for his support in the use of ESEM and all our colleagues at the Aquatic Ecology Laboratory.

\section{REFERENCES}

Andreoli, C., N. Rascio, F. Dalla Vecchia and L. Talarico. - 1989. An ultrastructural research on natural populations of picoplankton from two brackish water environments in Italy. J. Plankton Res., 11: 1067-1074.

Bachelet, G., X. de Montaudouin, I. Auby and P.J. Labourg. 2000. Seasonal changes in macrophyte and macrozoobenthos assemblages in three coastal lagoons under varying degrees of eutrophication. ICES J. Mar. Sci., 57: 1495-1506.

Carrick, H.J. and C.L. Schelske. - 1997. Have we overlooked the importance of small phytoplankton in productive waters? Lim- 
nol. Oceanogr., 42(7): 1613-1621.

Castel, J., P. Caumette and R. Herbert. - 1996. Eutrophication gradients in coastal lagoons as exemplified by the Bassin d'Arcachon and the Étang du Prèvost. Hydrobiology, 329: ix-xxviii.

Chomérat, N., R. Garnier, C. Bertrand and A. Cazaubon. - 2007. Seasonal succession of cyanoprokaryotes in a hyperetrophic oligo-mesohaline lagoon from the South of France. Estuar. Coast. Shelf Sci., 72: 591-602.

Crosbie, N.D., M. Pöckl and T. Weisse. - 2003. Dispersal and Phylogenetic Diversity of Nonmarine Picocyanobacteria, inferred from 16S rRNA Gene and $c p c B A$-Intergenic Spacer Sequence Analyses. Appl. Environ. Microbiol., 69: 5716-5721.

Del Negro, P., A. Paoli, M. Celussi, E. Crevatin, A. Valeri, C. Larato and S. Fonda Umani. - 2007. Picoplanktonic cyanobacteria in different Adriatic brackish environmrnts. Transit. Waters Bull., 3: $13-16$.

Findenegg, I. - 1974. Expressions of populations. In: R.A. Vollenweider (ed.), A Manual on Methods for Measuring Primary Production in Aquatic Environments, pp. 16-48. Blackwell Scientific Publications, Oxford.

Gasiūnaité, Z.R., A.C. Cardoso, A.S. Heiskanen, P. Henriksen, P. Kauppila, I. Olenina, R. Pilkaitytè, I. Purina, A. Razinkovas, S. Sagert, H. Schubert and N. Wasmund. - 2005. Seasonality of coastal phytoplankton in the Baltic Sea: influence of salinity and eutrophication. Estuar. Coast. Shelf Sci., 65: 239-252.

Glibert, P.M., C.E. Wazniak, M.R. Hall and B. Sturgis. - 2007. Seasonal and interannual trends in nitrogen and brown tide in Maryland's coastal bays. Ecol. Appl., 17(5): S79-S87.

Hindák, F. - 2000. Morfological variation of four planktic nostocalean cyanophytes-memnbers of the genus Aphanizomenon or Anabaena? Hydrobiologia, 438: 107-116.

Huszar, V.L.M., L.H.S. Silva, M. Marinho, P. Domingos and C.L. Sant'Anna. - 2000. Cyanoprokaryote assemblages in eight productive tropical Brazilian waters. Hydrobiologia, 424: 67-77.

Kanoschina, I., U. Lips and J.M. Leppänen. - 2003. The influence of weather conditions (temperature and wind) on cyanobacterial bloom development in the Gulf of Finland (Baltic Sea). Harmful Algae, 2: 29-41.

Komárek, J. - 2005. Phenotype diversity of the heterocytous cyanoprokaryotic genus Anabaenopsis. Czech Phycol., Olomouc, 5. $1-35$.

Komárek, J. and K. Anagnostidis. - 1998. Cyanoprokariota, 1 teil: Chroococcales. In: H. Ettl, G. Gärtner, H. Heynig and D. Mollenhauer (eds.), Sübwasserflora von Mitteleuropa, pp. 548. Band 19/1. Gustav Fisher, Berlin.

Komárek, J. and K. Anagnostidis. - 2005. Cyanoprokariota, 2 teil: Oscillatoriales. In: B. Büdel, L. Krienitz, G. Gärtner and M. Schagerl (eds.), Sübwasserflora von Mitteleuropa, pp. 759. Band 19/2. Elsevier, Munich.

Komárek, J. and J. Komárková-Legnerová. - 2002. Contribution to the knowledge of planktic cyanoprokaryotes from central Mexico. Preslia, 74: 207-233.

Komárek, J. and L. Kováčik. - 1989. Trichome structure of four Aphanizomenon taxa (Cyanophyceae) from Czechoslovakia, with notes on the taxonomy and delimitation of the genus. Plant Syst. Evol., 164: 47-64.

Morán, X.A.G. - 2007. Annual cycle of picophytoplankton photosynthesis and growth rates in a temperate coastal ecosystem: a mayor contribution to carbon fluxes. Aquat. Micro. Ecol., 49: 267-279.

Padedda, B.M., A. Lugliè, G. Ceccherelli, F. Trebini and N. Sechi. -2010 . Nutrient-flux evaluation by the LOICZ Biogeochemical Model in Mediterranean lagoons: the case of Cabras Lagoon (Central-Western Sardinia). Chem. Ecol., 26(2): 147-162.

Padisák, J., L.O. Crossetti and L. Naselli-Flores. - 2009. Use and misuse in the application of the phytoplankton functional classification: a critical review with updates. Hydrobiologia, 621: $1-19$.

Paoli, A., M. Celussi, A.Valeri, C. Larato, A. Bussani, S.F. Umani, M.R. Vadrucci, C. Mazziotti and P. Del Negro. - 2007. Picocyanobacteria in Adriatic transitional environments. Estuar. Coast. Shelf Sci., 75: 13-20.

Pérez, M.C. and A. Carrillo. - 2005. Picocyanobacteria distribution in the Ebro Estuary (Spain). Acta Bot. Croat., 64(2): 237-246.

Reynolds, C.S., V. Huszar, C. Kruk, L. Naselli-Flores and S. Melo. - 2002. Towards a functional classification of the freshwater phytoplankton. J. Plankton Res., 24(5): 417-428.

Romo, S. and M.R. Miracle. - 1993. Long term periodicity of Planktothrix agardhii, Pseudanabaena galeata and Geitlerinema sp. in a shallow hypertrophic lagoon, the Albufera of Valencia (Spain). Arch. Hydrobiol., 126: 469-486.

Scheffer, M., S. Rinaldi, A. Gragnani, L.R. Mur and E.H. van Nes. -1997 . On the dominance of filamentous cyanobacteria in shallow, turbid lakes. Ecology, 78(1): 272-282.

Scheffer, M., S. Carpenter, J.A. Foley, C. Folke and B. Walker. 2001. Catastrophic shifts in ecosystems. Nature, 413: 591-596.

SCOR-UNESCO. - 1966. Determination of photosynthetic pigments in sea water. UNESCO Monographs on Oceanographic Methodology. UNESCO, Paris.

Sechi, N. - 1982. Lo stato trofico di alcuni stagni salmastri costieri della Sardegna. Boll. Soc. Sarda Sci. Nat., 21: 285-295.

Sechi, N., B.M. Padedda and A. Lugliè. - 2006. Gestione ecologica e territoriale di ambienti di transizione: lo Stagno di Cabras. In: G. Maciocco and P. Pittaluga (eds.), Il progetto ambientale in aree di bordo, pp. 206-237. Franco Angeli Editore, Milano.

Sorokin, Yu.I., P.Yu. Sorokin and A. Gnes. - 1996. Structure and functioning of antropogenically transformed Comacchio lagoon ecosystem (Ferrara, Italy). Mar. Ecol. Prog. Ser., 133: 57-71.

Stal, L.J. and J.P. Zehr. - 2008. Cyanobacterial Nitrogen Fixation in the Oceans: Diversity, Regulation and Ecology. In: A. Herrero and E. Flores (eds.), The Cyanobacteria: Molecular Biology, Genetics and Evolution, pp. 423-441. Caister Academic Press, Norfolk, UK.

Strickland, J.D.H. and T.R. Parsons. - 1972. A pratical handbook of seawater analysis. Bull. Fish. Res. Board Can., pp. 167.

Ter Braak, C.J.F. - 1986. Canonical correspondence analysis: a new eigenvector technique for multivariate direct gradient analysis. Ecology, 67: 1167-1179.

Utermöhl, H. - 1931. Neue Wege in der quantitativen Erfassung des Planktons. Verh. Internat. Verein. Limnol., 5: 567-596.

Viaroli, P., P. Lasserre and P. Campostrini. - 2007. Lagoons and coastal wetlands. Hydrobiologia, 577: 1-3.

Scient. ed.: D. Vaqué.

Received November 13, 2009. Accepted June 15, 2010.

Published online December 23, 2010. 